\title{
INHIBITION OF ASCORBIC-ACID-INDUCED DEPOLYMERIZATION OF HYALURONIC ACID BY CERULOPLASMIN IN SYNOVIAL FLUID*
}

\author{
BY \\ WILLIAM NIEDERMEIER \\ From the Division of Rheumatic Diseases, Department of Medicine, The Medical Center, \\ University of Alabama, Birmingham, Ala
}

It has been demonstrated in vitro that low concentrations of ascorbic acid rapidly depolymerize purified hyaluronic acid as judged from viscosity measurements (Skanse and Sundblad, 1943; Pigman, Rizvi, and Holley, 1961). Abrams and Sandson (1964) reported that the hyaluronic acid in rheumatoid synovial fluid is resistant to depolymerization by ascorbic acid in vitro. Serum proteins have been shown to inhibit the action of ascorbic acid on purified hyaluronic acid. The alpha-2 globulin fraction was found to contain the serum proteins most active in inhibiting the reaction (De Salegui, Rizvi, Holley, and Pigman, 1962; Pigman and Rizvi, 1959). The increased concentration of blood serum proteins in synovial fluid from patients with rheumatoid arthritis has been repeatedly reported since the original observation of Ropes and Bauer (1953), and the marked increase in alpha-2 globulins has been noted by Binette and Schmid (1965). Reports from this laboratory showed that the concentrations of haptoglobin (Niedermeier, Cross, and Beetham, 1965) and ceruloplasmin (Niedermeier, 1965a), which are both alpha-2 glycoproteins, are markedly raised in synovial fluid of patients with rheumatoid arthritis. Ceruloplasmin has been shown to inhibit ascorbic acid-induced depolymerization of purified preparations of hyaluronic acid (Niedermeier, 1965b, 1966).

The present studies were undertaken to determine whether the presence of ceruloplasmin in increased amounts could account for the failure of ascorbic acid to depolymerize hyaluronic acid in synovial fluid from patients with rheumatoid arthritis.

\section{Material and Methods}

Material.-Purified hyaluronic acid that contained less than 4 per cent. protein was prepared from cattle synovial fluid by the cetylpyridinium chloride precipitation method

\footnotetext{
* Supported by grants from the National Institute of Arthritis and Metabolic Diseases, National Institutes of Health, Bethesda, Maryland, and Merck Sharp and Dohme, West Point, Pennsylvania.
}

(Matsumura, De Salegui, Herp, and Pigman, 1963). The preparation used in these studies had a hyaluronic acid concentration of $207 \mathrm{mg}$. $/ 100 \mathrm{ml}$. and an intrinsic viscosity of $46 \mathrm{dl} . / \mathrm{g}$.

Synovial fluid specimens were collected from the knee joints of seven cadavers, selected at random, without evidence of rheumatic disease and from eight living patients who had definite or classical rheumatoid arthritis (Ropes, Bennett, Cobb, Jacox, and Jessar, 1957). The specimens were stored at $2^{\circ} \mathrm{C}$. until used. To some of the specimens from patients with rheumatoid arthritis an equal volume of purified hyaluronic acid was added in order to increase their hyaluronic acid concentration and viscosity to values comparable to those of the post mortem specimens. The analytical values listed in Table II for intrinsic viscosity, hyaluronic acid concentration, and ceruloplasmin concentration of solutions prepared from rheumatoid synovial fluid were obtained after addition of purified hyaluronic acid to the synovial fluids.

Purified ceruloplasmin was supplied by the American National Red Cross and A. B. Kabi, Stockholm. Tiselius electrophoresis in veronal buffer, $0 \cdot 1 \mu$ at $\mathrm{pH} 8.6$ showed that, in addition to ceruloplasmin which had a mobility of $4 \cdot 6$, all the preparations contained a contaminant with a mobility of 5.50 which probably represented an alpha-1 globulin. Two preparations that contained different proportions of what appeared electrophoretically to be the same contaminant had essentially the same activity per mg. ceruloplasmin in protecting hyaluronic acid from depolymerization by ascorbic acid, indicating that the results obtained represent the activity of ceruloplasmin and not the alpha-1 globulin contaminant. Reagent grade L-ascorbic acid was purchased from J. T. Baker Chemical Company.

Ceruloplasmin concentration was determined on the basis of its capacity to oxidize paraphenylenediamine by the method of Scheinberg and Morell (1957). Total protein was determined by the Phenol method (Lowry, Rosebrough, Farr, and Randall, 1951). Hyaluronic acid was determined by the method of Dische (1947).

Depolymerization as measured by Changes in Specific Viscosity.-All experiments involving the effect of ascorbic acid on viscosity of purified hyaluronic acid were 
conducted on solutions that contained $70 \mathrm{mg}$. per cent. hyaluronic acid, $0.08 \mathrm{mM} / 1$. ascorbic acid and $0.2 \mathrm{M}$ phosphate buffer at $\mathrm{pH} 7 \cdot 4$. After the addition of a freshly-prepared solution of ascorbic acid, which was the last reagent added, a stop-watch was started. The solution was thoroughly mixed and an aliquot placed in a CannonManning semi-micro viscometer maintained at a constant temperature of $30^{\circ} \mathrm{C}$. The flow time was recorded within 3 minutes after the addition of ascorbic acid and was repeated at intervals for up to 12 hours. From the flow time of $0.2 \mathrm{M}$ phosphate buffer, in the same viscometer, specific fluidities $(\phi=1 . / \eta \mathrm{sp})$ were calculated and plotted as a function of time. The increase in fluidity was essentially linear during the first 2 hours of reaction. The results were expressed in terms of change in specific fluidity per minute ( $\Delta \phi / \mathrm{min}$.) during the first 30 minutes of the reaction.

\section{Results}

The typical effects of $0.08 \mathrm{mM} / 1$. ascorbic acid on depolymerization of hyaluronic acid in post mortem synovial fluid (PMSF), rheumatoid synovial fluid (RASF), and rheumatoid synovial fluid to which purified hyaluronic acid (RASF + HA) was added are compared with its effect on purified hyaluronic acid (HA) in the Figure. The initial rate of depolymerization of purified hyaluronic acid was considerably greater than that of hyaluronic acid in post mortem synovial fluid. In the presence of rheumatoid synovial fluid, neither endogenously present hyaluronic acid nor purified hyaluronic acid added to the fluid were appreciably depolymerized by $0.08 \mathrm{mM} / 1$. ascorbic acid.

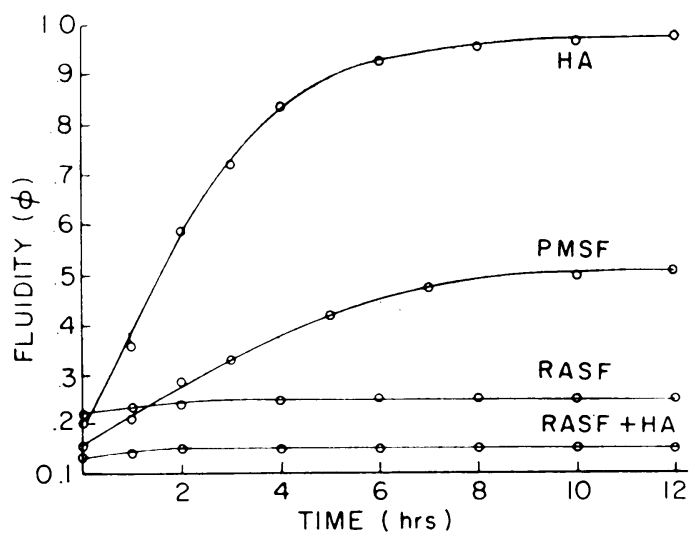

Fig. 1.-Effect of $0.08 \mathrm{mM} / \mathrm{l}$. ascorbic acid on the fluidity of human post mortem synovial fluid (PMSF), rheumatoid synovial fluid (RASF), rheumatoid synovial fluid to which purified hyaluronic acid from rheumatoid synovial fluid to which purified hyaluronic acid from purified hyaluronic acid from cattle synovial fuid (HA). All solutions were prepared in $0 \cdot 2 \mathrm{M}$ phosphate buffer, $\mathrm{pH} 7 \cdot 4$.

The effect of $0.08 \mathrm{mM} / \mathrm{l}$. ascorbic acid on depolymerization of hyaluronic acid was determined in seven specimens of post mortem synovial fluid and in eight specimens of rheumatoid synovial fluid to which purified hyaluronic acid was added as show in Table $I$. The ceruloplasmin and hyaluronic aci concentrations indicated in the Table represent the. concentrations in the solutions on which. viscosity measurements were made. The mea $\overrightarrow{\overrightarrow{5}}$ ceruloplasmin concentration in solutions prepare ${ }^{+}$ from seven specimens of post mortem synovial fluif was $1.0 \mathrm{mg}$. per cent. and the mean rate of increase $i \overline{\overline{\text { F}}}$. fluidity was $0.008 \phi$ units $/ \mathrm{min}$. The mean cerulo plasmin concentration in solutions prepared from eight specimens of rheumatoid synovial fluid was $4.3 \mathrm{mg}$. per cent. and the rate of increase in fluidit $\bar{\phi}$ was less than $0.001 \phi$ units/min., or more than 87.5 per cent. less than that in those prepared frorg post mortem synovial fluid.

TABLE I

ASCORBIC ACID*-INDUCED DEPOLYMERIZATION OF * HYALURONIC ACID IN SYNOVIAL FLUID

\begin{tabular}{|c|c|c|c|c|c|c|}
\hline \multirow{2}{*}{$\begin{array}{l}\text { Synovial } \\
\text { Fluid }\end{array}$} & \multirow{2}{*}{$\begin{array}{l}\text { Specimen } \\
\text { No. }\end{array}$} & \multicolumn{2}{|c|}{$\begin{array}{l}\text { Hyaluronic } \\
\text { Acid }\end{array}$} & \multirow{2}{*}{ 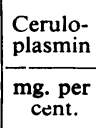 } & \multicolumn{2}{|c|}{ Fluidity } \\
\hline & & {$[\eta] \dagger$} & $\begin{array}{l}\text { mg. per } \\
\text { cent. }\end{array}$ & & Initial & $\triangle \phi / \mathrm{mi} \stackrel{\complement}{\beth}$ \\
\hline \multirow{8}{*}{$\begin{array}{l}\text { Post } \\
\text { mortem }\end{array}$} & 9 & $42 \cdot 5$ & $55 \cdot 5$ & - & $0 \cdot 178$ & 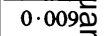 \\
\hline & 11 & $49 \cdot 5$ & $71 \cdot 6$ & 0.5 & 0.145 & 0.007 \\
\hline & 12 & $51 \cdot 5$ & $65 \cdot 4$ & $1 \cdot 0$ & $0 \cdot 222$ & 0.00 \\
\hline & 13 & $47 \cdot 0$ & $61 \cdot 4$ & $1 \cdot 2$ & $0 \cdot 150$ & \\
\hline & 14 & $64 \cdot 0$ & $50 \cdot 0$ & $1 \cdot 1$ & 0.212 & 0.08 \\
\hline & 15 & $56 \cdot 0$ & $62 \cdot 6$ & $1 \cdot 3$ & $0 \cdot 195$ & $0.013 \overline{2}$ \\
\hline & 16 & $64 \cdot 0$ & $47 \cdot 3$ & 0.9 & $0 \cdot 197$ & 0.008 ำ \\
\hline & Mean & & & $1 \cdot 0$ & & 0.008 \\
\hline \multirow{9}{*}{$\begin{array}{l}\text { Patients } \\
\text { with } \\
\text { Rheuma- } \\
\text { toid } \\
\text { Arthritis }\end{array}$} & 17 & - & $63 \cdot 5$ & $5 \cdot 75$ & 0.331 & \\
\hline & 18 & $30 \cdot 5$ & $60 \cdot 1$ & $4 \cdot 85$ & $0 \cdot 351$ & 0.0013 \\
\hline & 19 & $40 \cdot 5$ & $50 \cdot 1$ & $5 \cdot 95$ & $0 \cdot 380$ & -0 \\
\hline & 20 & $39 \cdot 0$ & $65 \cdot 5$ & $6 \cdot 40$ & $0 \cdot 292$ & -0 \\
\hline & 21 & $33 \cdot 5$ & $70 \cdot 5$ & $5 \cdot 00$ & 0.311 & 0.0010 \\
\hline & 22 & $35 \cdot 0$ & $103 \cdot 5$ & $4 \cdot 05$ & $0 \cdot 250$ & -0 \\
\hline & 23 & $28 \cdot 0$ & $104 \cdot 5$ & $3 \cdot 00$ & $0 \cdot 146$ & $-0-\overline{8}$ \\
\hline & 24 & $20 \cdot 0$ & $85 \cdot 0$ & $3 \cdot 45$ & $0 \cdot 216$ & $-0-3$ \\
\hline & Mean & & & $4 \cdot 3$ & & $\begin{array}{c}\text { Less that } \\
0.00 \mathrm{P}\end{array}$ \\
\hline
\end{tabular}

The capacity of ceruloplasmin to inhibit depolys merization of hyaluronic acid in a purified preparaw tion under the same conditions was approximately proportional to its concentration as shown in Tabf II (opposite).

In the absence of ceruloplasmin, $0.08 \mathrm{mM} / \mathrm{\&}$ ascorbic acid effected an increase in fluidity of the solution of $0.0134 \phi$ units $/ \mathrm{min}$. In the presence $\frac{d}{d}$ 
$5 \mathrm{mg}$. per cent. ceruloplasmin, the hyaluronic acid underwent depolymerization at a rate equivalent to $0.0116 \phi$ units $/ \mathrm{min}$. or 13.6 per cent. less than in the absence of ceruloplasmin. In order to obtain changes in fluidity equivalent to those observed for post mortem and rheumatoid synovial fluid it was necessary to increase the ceruloplasmin concentration to 50 and $100 \mathrm{mg}$. per cent. respectively.

TABLE II

EFFECT OF CERULOPLASMIN ON ASCORBIC ACIDINDUCED DEPOLYMERIZATION OF PURIFIED HYALURONIC ACID

\begin{tabular}{c|c|c}
\hline $\begin{array}{c}\text { Ceruloplasmin } \\
\begin{array}{c}\text { Concentration } \\
\text { (mg. per cent.) }\end{array}\end{array}$ & \multicolumn{2}{|c}{ Fluidity $\phi$} \\
\hline 0 (Control) & $\Delta \phi /$ min. & per cent. Inhibition* \\
\hline 5 & 0.0134 & - \\
\hline 10 & 0.0116 & 13.6 \\
\hline 50 & 0.0096 & 53.8 \\
\hline 100 & 0.0012 & $91 \cdot 0$ \\
\hline 0.0007 & 94.4 \\
\hline
\end{tabular}

* per cent. inhibition $=$

$\frac{\Delta \phi \text { Control }-\Delta \phi \text { in presence of ceruloplasmin }}{\Delta \phi \text { control }} \times 100$

The effect of ceruloplasmin on the rate of depolymerization of hyaluronic acid in post mortem synovial fluid is compared with its effect on purified hyaluronic acid in Table III. The ceruloplasmin concentration of a pool consisting of three post mortem synovial fluid specimens was determined. The pooled specimen was divided into four aliquots. Purified ceruloplasmin was added to three of the aliquots to a concentration of 10,50 , and $100 \mathrm{mg}$. per cent. respectively. No ceruloplasmin was added to the fourth aliquot which served as a control. The effect of ascorbic acid on depolymerization in these

TABLE III

EFFECT OF CERULOPLASMIN ADDED TO POST MORTEM SYNOVIAL FLUID (SF) AND TO PURIFIED HYALURONIC ACID ON THE ASCORBIC ACID-INDUCED DEPOLYMERIZATION OF HYALURONIC ACID (HA)

\begin{tabular}{|c|c|c|c|c|c|}
\hline \multirow{2}{*}{$\begin{array}{c}\text { Experi- } \\
\text { ment } \\
\text { No. }\end{array}$} & \multirow{2}{*}{$\begin{array}{c}\text { Cerulo- } \\
\text { plasmin } \\
\text { (mg. per } \\
\text { cent.) }\end{array}$} & \multirow{2}{*}{ Substrate } & \multicolumn{3}{|c|}{ Fluidity $(\phi)$} \\
\hline & & & Initial & $\Delta \phi / \min$. & $\begin{array}{l}\text { per cent. } \\
\text { Inhibition* }\end{array}$ \\
\hline 1 & $\begin{array}{c}0.4 \\
\text { (Control) }\end{array}$ & $\begin{array}{l}\text { (SF) } \\
\text { (HA) }\end{array}$ & $\begin{array}{l}0 \cdot 1503 \\
0 \cdot 2000\end{array}$ & $\begin{array}{l}0.0026 \\
0.0112\end{array}$ & $=$ \\
\hline 2 & 10 & (SF) & $\begin{array}{l}0 \cdot 1703 \\
0 \cdot 1689\end{array}$ & $\begin{array}{l}0.0011 \\
0.0050\end{array}$ & $\begin{array}{l}57.5 \\
55.4\end{array}$ \\
\hline 3 & 50 & $\begin{array}{l}\text { (SF) } \\
\text { (HA) }\end{array}$ & $\begin{array}{l}0 \cdot 1639 \\
0 \cdot 1683\end{array}$ & $\begin{array}{l}0.0008 \\
0.0020\end{array}$ & $\begin{array}{l}69 \cdot 3 \\
82 \cdot 2\end{array}$ \\
\hline 4 & 100 & $\begin{array}{l}\text { (SF) } \\
(\mathbf{H A})\end{array}$ & $\begin{array}{l}0 \cdot 1533 \\
0 \cdot 1661\end{array}$ & $\begin{array}{l}0.0004 \\
0.0011\end{array}$ & $\begin{array}{l}84 \cdot 7 \\
90 \cdot 3\end{array}$ \\
\hline
\end{tabular}

*per cent. inhibition $=$ $\frac{\Delta \phi \text { Control }-\Delta \phi \text { in presence of ceruloplasmin }}{\Delta \phi \text { control }} \times 100$ solutions was compared with its effect on solutions of purified hyaluronic acid to which was added the same concentrations of ceruloplasmin. The rate of increase in fluidity of the solutions that contained purified hyaluronic acid was between two and four times greater than that of the solution prepared from synovial fluid which contained the same concentration of ceruloplasmin. Based on the rate of depolymerization of the respective solution to which no ceruloplasmin was added, the percentage inhibition due to ceruloplasmin was essentially the same in synovial fluid as it was in the solutions that contained purified hyaluronic acid.

The capacity of blood serum to inhibit depolymerization of purified hyaluronic acid is demonstrated by the data presented in Table IV (overleaf).

Three serum specimens, selected on the basis of their content of ceruloplasmin, from a patient with Wilson's disease, a patient with rheumatoid arthritis, and a "normal" volunteer, contained $5 \cdot 2,76$, and $28 \mathrm{mg}$. per cent. ceruloplasmin respectively. These were added in the quantities indicated in Table IV to solutions of purified hyaluronic acid and their capacity to inhibit ascorbic acid induced depolymerization was determined. The concentrations of total protein and ceruloplasmin indicated in the Table represent the final concentrations in the solution on which viscosities were determined. All three blood serum specimens were potent inhibitors of depolymerization. Their capacity to inhibit the reaction was greatly in excess of that which could be attributed to their ceruloplasmin content. Even the specimen of blood serum from the patient with Wilson's disease, which contributed only minute quantities of ceruloplasmin, was a potent inhibitor. The addition of $0.25 \mathrm{ml}$. rheumatoid blood serum contributed only $9.5 \mathrm{mg}$. per cent. ceruloplasmin to the solution. The fluidity of this solution increased at the rate of only $0.0003 \phi$ units/min., 97.5 per cent. less than that of the solution in the absence of added blood serum or ceruloplasmin. As noted in Table II, the increase in fluidity of a solution of purified hyaluronic acid in the presence of $10 \mathrm{mg}$. per cent. ceruloplasmin was $0.0096 \phi$ units/min., only $53.8 \mathrm{per}$ cent. less than that in the absence of ceruloplasmin.

When considered on the basis of total protein concentration, however, ceruloplasmin was a more effective inhibitor than whole blood serum. In the presence of $100 \mathrm{mg}$. per cent. ceruloplasmin, as noted in Table II, the fluidity increased only $0.0007 \phi$ units/min., $94 \cdot 4$ per cent. less than the comparable solution which contained no ceruloplasmin. In the presence of $200 \mathrm{mg}$. per cent. blood serum proteins 
EFFECT OF BLOOD SERUM ON ASCORBIC ACID-INDUCED DEPOLYMERIZATION OF PURIFIED HYALURONIC ACIDC

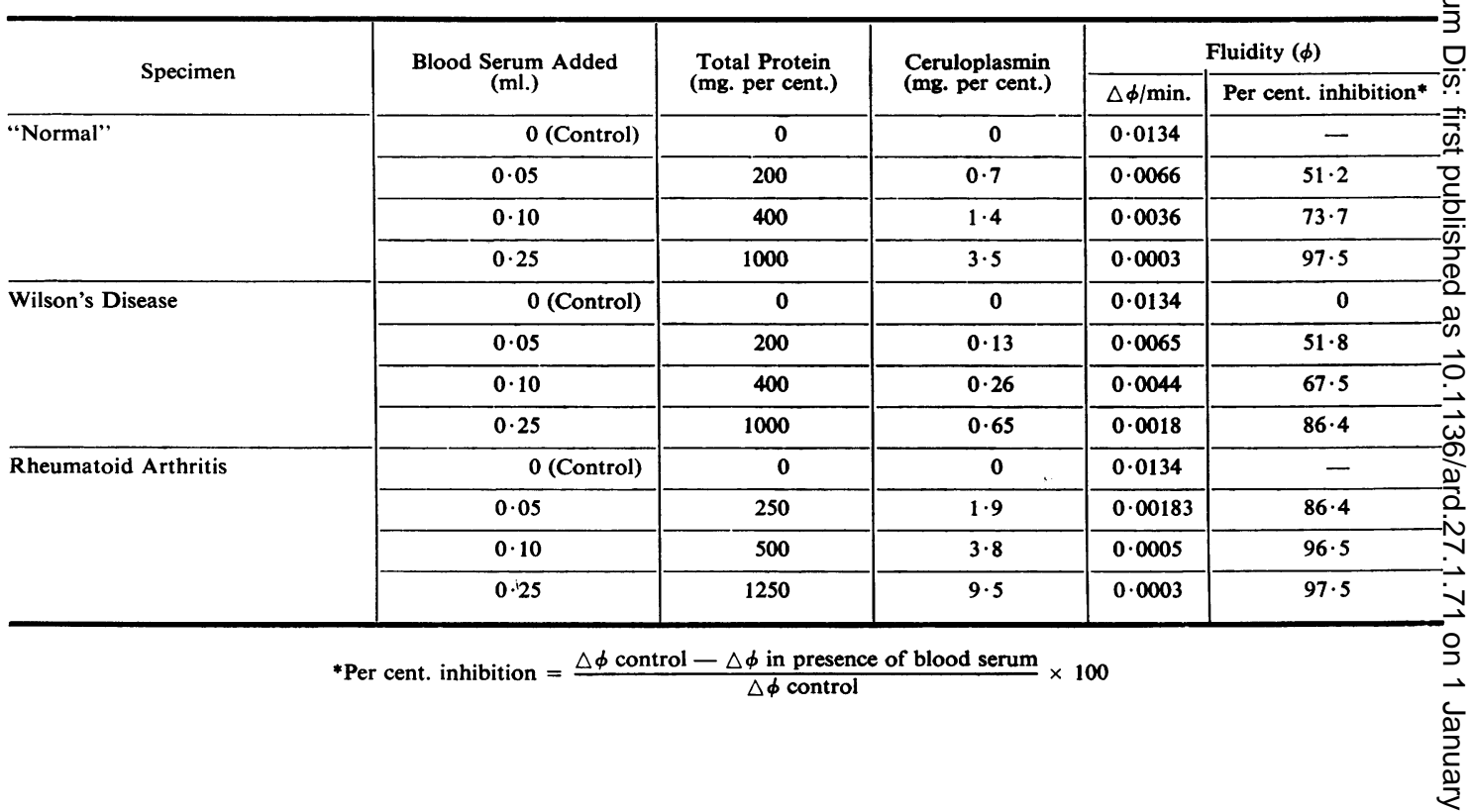

from either the patient with Wilson's disease or the "normal" volunteer, fluidity increased at the rate of 0.0065 units $/ \mathrm{min}$., 51 per cent. of that for the comparable solution to which no blood serum proteins were added.

\section{Discussion}

Abrams and Sandson (1964) reported that hyaluronic acid in rheumatoid synovial fluid was resistant to depolymerization by ascorbic acid and suggested that the factor responsible for inhibition of the reaction was an alpha-2 globulin. The present studies also demonstrated the resistance of hyaluronic acid in rheumatoid synovial fluid to depolymerization by $0.08 \mathrm{mM} / 1$. ascorbic acid. The hyaluronic acid present in post mortem synovial fluid from cadavers without evidence of rheumatic disease underwent depolymerization, but at a slower rate than in solutions that contained purified hyaluronic acid in the absence of synovial fluid. By increasing the ascorbic acid concentration to $0.32 \mathrm{mM} / 1$, depolymerization of hyaluronic acid in rheumatoid synovial fluid could be demonstrated. Purified hyaluronic acid from cattle synovial fluid, when added to rheumatoid synovial fluid, was also resistant to depolymerization. This supported the hypothesis that the failure of ascorbic acid to increase the fluidity of the solution was due to the presence of inhibiting factors rather than to a difference in molecular structure or configuration of hyaluronic acid endogenously present in rheumatoid synoviabo fluid. The capacity of ceruloplasmin to inhigite depolymerization was approximately the same đํ post mortem synovial fluid as it was in solutions of purified hyaluronic acid.

The experiments in which the effect of bloodहै serum on the depolymerization of hyaluronic acid by ascorbic acid was studied revealed that, on the basis of total protein concentration, whole bloods serum was less effective than ceruloplasmin in inhibiting the reaction. The activity of whole blood़ serum was greater, however, than could be accounted for on the basis of its ceruloplasmin concentration $\bar{e}$ The results indicate that blood serum contains some factor in addition to ceruloplasmin that inhibits the depolymerization of hyaluronic acid by ascorbie acid. This factor, which appears to act independently of ceruloplasmin, is probably also present in synoviaf fluid. Its concentration, like that of serum proteinss in general, is probably raised in the synovial fluid os patients with rheumatoid arthritis. There is the possibility that purified ceruloplasmin was less active than that endogenously present in blood serum dues to partial denaturation of the glycoprotein duringw the process of isolation and purification. Smal differences in activity of different purified ceruloo plasmin preparations were noted.

The observation that hyaluronic acid in synoviaf fluid of patients with rheumatoid arthritis is depoly $=0$ merized in the presence of raised concentrations of 
ceruloplasmin and a second factor which inhibits depolymerization of hyaluronic acid is difficult to explain. It is suggested that, in the joints of these patients, hyaluronic acid is depolymerized by a mechanism other than that involving ascorbic acid, and that the increase in ceruloplasmin concentration is a secondary event which may inhibit further depolymerization by the reaction involving ascorbic acid.

It cannot be precluded that the results of the present study were not influenced by post mortem changes which take place in synovial fluid. Platt, Pigman, Holley, and Patton (1956) noted that the total nitrogen concentration and electrophoretic behaviour of the proteins in post mortem synovial fluid were the same as in normal human synovial fluid. They reported, however, that the NPN value for post mortem fluids was approximately three times that of the normal fluids. Stafford, Niedermeier, Holley, and Pigman (1964) demonstrated that the hyaluronic acid concentration of post mortem synovial fluid is about $\mathbf{4 0}$ per cent. less than that of normal volunteers. This difference was attributed to post mortem dilution of the fluid. It was also noted, however, that the intrinsic viscosity of hyaluronic acid in post mortem synovial fluid was essentially the same as that of hyaluronic acid in synovial fluid from normal volunteers.

Niedermeier (1965a) observed that, within the limits of normal variation and experimental error, the concentration of ceruloplasmin was the same in post mortem synovial fluid as in normal human synovial fluid.

\section{Summary and Conclusions}

The effect of ceruloplasmin on the ascorbic acid-induced depolymerization of hyaluronic acid as judged from changes in fluidity was studied. Hyaluronic acid in rheumatoid synovial fluid was more resistant to depolymerization by ascorbic acid than that in post mortem synovial fluid. The increased concentration of ceruloplasmin in synovial fluid from patients with rheumatoid arthritis is probably in part responsible for this difference. Other factors appear to be present in blood serum and probably also in synovial fluid which are active in inhibiting ascorbic acid-induced depolymerization of hyaluronic acid.

\section{REFERENCES}

Abrams, E., and Sandson, J. (1964). Ann. rheum. Dis., 23, 295 (Effect of ascorbic acid on rheumatoid synovial fluid).

Binette, J. P., and Schmid, K. (1965). Arthr. and Rheum., 8, 14 (The proteins of synovial fluid: a study of the $a_{1} / a_{2}$ globulin ratio).

De Salegui, M., Rizvi, S., Holley, H. L., and Pigman, W. (1962). Fed. Proc., 21, 171 (The degradation of hyaluronic acid by proteins).

Dische, Z. (1947). J. biol. Chem., 167, 189 (A new specific color reaction of hexuronic acids).

Lowry, O. H., Rosebrough, N. J., Farr, A. L., and Randall, R. J. (1951). Ibid., 193, 265 (Protein measurement with the folin phenol reagent).

Matsumura, G., De Salegui, M., Herp, A., and Pigman, W. (1963). Biochim. biophys. Acta, 69, 574 (The preparation of hyaluronic acid from bovine synovial fluid).

Niedermeier, W. (1966). Clin. Res., 14, 93 (Inhibition of ascorbic acid-induced depolymerization of hyaluronic acid by ceruloplasmin).

(1965a). Ann. rheum. Dis., 24, 544 (Concentration and chemical state of copper in synovial fluid and blood serum of patients with rheumatoid arthritis).

(1965b). Ala. J. med. Sci., 2, 196 (The effect of ceruloplasmin on the state of polymerization of hyaluronic acid).

-, Cross, R., and Beetham, W. P., Jr. (1965). Arthr. and Rheum., 8, 355 (The concentration of haptoglobin in synovial fluid of patients with rheumatoid arthritis).

Pigman, W., and Rizvi, S. (1959). Biochem. biophys. Res. Comm., 1, 39 (Hyaluronic acid and the ORD reaction).

,-- , and Holley, H. L. (1961). Arthr. and Rheum., 4, 240 (Depolymerization of hyaluronic acid by the ORD reaction).

Platt, D., Pigman, W., Holley, H. L., and Patton, F. M. (1956). Arch. Biochem. Biophys., 64, 152 (An electrophoretic study of normal and post-mortem human and bovine synovial fluids).

Ropes, M. W., and Bauer, W. (1953). "Synovial Fluid Changes in Joint Disease." Harvard Univ. Press, Cambridge, Mass.

—, Bennett, G. A., Cobb, S., Jacox, R., and Jessar, R. A. (1957). J. chron. Dis., 5, 630 (Proposed diagnostic criteria for rheumatoid arthritis). 
Scheinberg, I. H., and Morell, A. G. (1957). J. clin. Invest., 36, 1193 (Exchange of ceruloplasmin copper with ionic $\mathrm{Cu}^{64}$ with reference to Wilson's disease).

Skanse, B., and Sundblad, L. (1943). Acta physiol. scand., 6, 37 (Oxidative breakdown of hyaluronic and chondroitin sulphuric acid).

Stafford, C. T., Niedermeier, W., Holley, H. L., and Pigman, W. (1964). Ann. rheum. Dis., 23, 152 (Studies on the concentration and intrinsic viscosity of hyaluronic acid in synovial fluids of patients with rheumatic diseases).

Inhibition par la céruloplasmine de la dépolymérisation de l'acide hyaluronique, induite par l'acide ascorbique, dans le liquide synovial

\section{RÉSUMÉ}

On étudia l'effet de la céruloplasmine sur la dépolymérisation de l'acide hyaluronique induite par l'acide ascorbique en fonction des modifications de la fluidité. L'acide hyaluronique du liquide synovial rhumatoïde était plus résistant à la dépolymérisation par l'acide ascorbique que celui du liquide synovial du cadavre. La concentration accrue en céruloplasmine dans le liquide synovial des malades atteints de polyarthrite rhumatoïde est probablement responsable en partie de cette différence. D'autres facteurs semblent exister dans le sérum sanguin et probablement aussi dans le liquide synovial, qui sont capables d'inhiber la dépolymérisation de l'acide hyaluronique induite par l'acide ascorbique.
Inhibición por la ceruloplasmina de la depolimerización del ácido hialurónico, inducida por el ácido ascórbico, eñ el líquido sinovial

\section{SUMARIO}

Se estudió el efecto de la ceruloplasmina sobre depolimerización del ácido hialurónico, inducida por $€$ ácido ascórbico en función de las modificaciones de 19 fluidez. El ácido hialurónico del líquido sinovial reuma-y toide fué más resistente a la depolimerización por el ácido ascórbico que él del líquido sinovial recogido post mortem. La concentración aumentada de ceruloplasmina en el líquido sinovial de enfermos con artritis reumatoide se debe probablemente, en parte, a esta diferencia. Otros factores parecen existir en el suero sanguíneo y probable mente también en el líquido sinovial con la capacidad de inhibir la depolimerización del ácido hialurónicô inducida por el ácido ascórbico. 